\title{
Peran Perawat Terhadap Issue Keselamatan Pasien Pada Ruang IGD
}

\author{
Novrial Ahmad Hanif / Ahmadnovrial15@gmail.com
}

\section{PENDAHULUAN}

\section{Latar Belakang}

Keselamatan pasien atau patient safety merupakan sistem pelayanan rumah sakit yang memberikan asuhan pasien secara lebih aman. Termasuk didalamnya prosedur : mengukur (assessing) risiko, identifikasi, dan pengelolaan risiko terhadap pasien, pelaporan dan analisis insiden, kemampuan untuk menindaklanjuti insiden serta menerapkan solusi untuk mengurangi serta meminimalisasi risiko yang juga melalui komunikasi dengan pasien. Dapat dikatakan bahwa fokus utama patient safety adalah upaya yang dilakukan untuk menghindari terjadinya kesalahan

.(1) WHO mengestimasikan, 1 dari 10 pasien dirugikan selama mendapatkan pelayanan kesehatan di rumah sakit yang terjadi di negara-negara maju. Sedangkan di negara-negara berkembang, peluang pasien untuk dirugikan selama menerima perawatan kesehatan di rumah sakit lebih tinggi dibandingkan negara-negara industri. Risiko kejadian infeksi dalam pelayanan kesehatan di negara-negara berkembang 20 kali lebih besar dibandingkan negaranegara maju.

(2) Masalah kesehatan terkait patient safety pun kerap dikeluhkan di Indonesia. Departemen Kesehatan Republik Indonesia menyatakan bahwa data KTD, terlebih pada Kejadian Nyaris Cedera (Near Miss) masih sangat langka dalam pelaporan, namun terjadi peningkatan tuduhan terhadap malpraktik. Jika dibandingkan dengan negara-negara maju seperti Amerika dan Inggris yang memiliki standar pelayanan kesehatan lebih baik dari Indonesia, dapat dibayangkan angka KTD dan kesalahan medis yang terjadi di Indonesia dapat lebih besar pula.

(3) Pelayanan gawat darurat merupakan salah satu komponen pelayanan rumah sakit yang dilaksanakan di Instalasi Gawat Darurat (IGD). Adapun fungsi IGD adalah menyelenggarakan pelayanan asuhan medis dan asuhan keperawatan serta pelayanan pembedahan darurat bagi pasien yang datang dengan gawat darurat medis. Sebagai unit pelayanan yang menanggulangi penderita gawat darurat, IGD merupakan high clinical risks areas, oleh karena itu pelayanan di IGD harus dikelola sedemikian rupa sehingga pasien mendapatkan perawatan yang baik dan aman, salah satu upaya untuk mewujudkan pelayanan yang aman adalah kembali lagi dengan penerapan patient safety yang baik di IGD.

(4) Belum terdapat data mengenai kejadian terkait keselamatan pasien (patient safety) di IGD yang lengkap dan akurat di Indonesia, namun berdasarkan data Komite Keselamatan Pasien Rumah Sakit (KKPRS), tercatat pelaporan insiden keselamatan pasien (patient safety) yang terjadi di IGD pada 19 Januari 2010. Insiden yang terjadi berupa kesalahan pemberian obat oleh perawat IGD kepada pasien. 
(5) Training keselamatan pasien (patient safety) telah dilaksanakan secara rutin setiap satu tahun sekali bagi perawat Instalasi Gawat Darurat dengan tujuan meningkatkan dan merivew (pengulangan kembali) mengenai pengetahuan terkait keselamatan pasien (patient safety) pada perawat. Meskipun demikian, pada praktik perawat terkait keselamatan pasien (patient safety) di IGD RS X Semarang, masih terdapat beberapa hal yang belum sesuai dengan standar keselamatan pasien (patient safety) yang diterapkan, yang mengacu pada PERMENKES RI No 1691, yaitu praktik mencuci tangan dan penjelasan penggunaan gelang identitas

pada

pasien.

\section{TINJAUAN PUSTAKA}

Keselamatan Pasien (Patient Safety)

Keselamatan pasien (patient safety) rumah sakit merupakan suatu sistem dimana rumah sakit membuat pelayanan pasien menjadi lebih aman. Sistem tersebut meliputi penilaian risiko, identifikasi dan pengelolaan hal yang berhubungan dengan risiko pasien, pelaporan dan analisis insiden, kemampuan belajar dari insiden dan tindak lanjutnya serta implementasi solusi untuk meminimalisasi timbulnya risiko. Sistem tersebut diharapkan dapat mencegah terjadinya cedera yang disebabkan oleh suatu tindakan yang dilakukan atau tidak melakukan suatu tindakan yang seharusnya dilakukan.(3) Terdapat enam tujuan utama penanganan pasien dengan penerapan keselamatan pasien (patient safety) menurut PERMENKES RI No 1691 yeng berpedoman pada Joint Commision International, yaitu(6) :

a. Mengidentifikasi atau mendiagnosa pasien dengan benar Maksud dari sasaran ini adalah untuk melakukan dua kali pengecekan, yaitu: pertama, untuk identifikasi pasien sebagai individu yang akan menerima pelayanan atau pengobatan; dan kedua, untuk kesesuaian pelayanan atau pengobatan terhadap individu tersebut.(7) b. Meningkatkan komunikasi secara efektif Komunikasi efektif, yang tepat waktu, akurat, lengkap, jelas dan yang dapat dipahami oleh pasien akan mengurangi kesalahan, dan menghasilkan peningkatan keselamatan pasien.(7)

c. Meningkatkan keamanan dari high-alert medication Obat-obatan yang perlu diwaspadai (high-alert medications) merupakan obat yang sering menyebabkan kesalahan atau kesalahan serius. Kesalahan dapat terjadi bila perawat tidak mendapatkan orientasi yang baik dan dalam situasi darurat.(7)

d. Memastikan benar tempat, benar prosedur dan benar pembedahan pasien Salah lokasi, salah prosedur, pasiensalah pada operasi, adalah sesuatu yang sangat mengkhawatirkan dan tidak jarang terjadi di rumah sakit.(7)

e. Mengurangi infeksi dari pekerja kesehatan Infeksi biasanya dijumpai dalam semua bentuk pelayanan kesehatan termasuk infeksi saluran kemih, infeksi pada aliran darah (bloodstream infections) dan pneumonia (sering kali dihubungkan dengan ventilasi mekanis).(7)

f. Mengurangi terjadinya risiko jatuh pada pasien Jumlah kasus jatuh pada pasien cukup bermakna sebagai penyebab cedera bagi pasien rawat inap. 
Dalam

konteks

populasi/masyarakat yang dilayani, pelayanan yang disediakan, dan fasilitasnya, rumah sakit perlu mengevaluasi risiko pasien jatuh dan mengambil tindakan untuk mengurangi risiko cedera bila sampai jatuh. Perlunya keselamatan pasien (patient safety) diterapkan pada tindakan medis, dikarenakan kompleksnya rangkaian tindakan medis yang kerap dilakukan. Dimulai dengan diagnosa, pertolongan pertama, pemeriksaan laboratorium, pemberian obat hingga tindakan pembedahan yang memungkinkan terjadinya kesalahan-kesalahan medis.(7) Pengetahuan Pengetahuan merupakan hasil dari tahu, dan ini terjadi setelah seseorang melakukan pengindraan terhadap objek tertentu. Pengindraan terjadi melalui pancaindra manusia, yakni indra penglihatan, pendengaran, penciuman, perasa dan peraba. Namun sebagian besar pengetahuan manusia diperoleh melalui mata dan telinga.(8)

Terdapat berbagai macam cara yang telah digunakan untuk memperoleh kebenaran pengetahuan sepanjang sejarah, yaitu:

1) Cara Coba Salah (Trial and Error) Cara coba-coba ini dilakukan dengan menggunakan kemungkinan tersebut tidak berhasil, dicoba kemungkinan yang lain. Apabila tidak berhasil, maka akan dicoba kemungkinan yang lain lagi sampai didapatkan hasil yang mencapai kebenaran.

2) Cara Kekuasaan atau Otoritas Di mana pengetahuan diperoleh berdasarkan pada otoritas atau kekuasaan baik tradisi, otoritas pemerintahan, otoritas pemimpin agama, maupun ahli ilmu pengetahuan.
3) Berdasarkan Pengalaman Pribadi Hal ini dilakukan dengan cara mengulang kembali pengalaman yang diperoleh dalam memecahkan permasalahan yang dihadapi pada masa yang lalu. Apabila dengan cara yang digunakan tersebut orang dapat memecahkan masalah yang sama, orang dapat pula menggunakan cara tersebut.

4) Melalui Jalan Pikiran Dari sini manusia telah mampu menggunakan penalarannya dalam memperoleh pengetahuannya. Dengan kata lain, dalam memperoleh kebenaran pengetahuan, manusia telah menggunakan jalan pikiran.

5) Cara baru atau modern dalam memperoleh pengetahuan pada dewasa ini lebih sistematis, logis, dan ilmiah. Cara ini disebut metode penelitian ilmiah.

Faktor-Faktor yang mempengaruhi pengetahuan adalah :

1) Usia Usia berpengaruh terhadap daya tangkap dan pola pikir seseorang. Semakin bertambah usia seseorang, akan semakin berkembang pula daya tangkap dan pola pikirnya, sehingga pengetahuan yang diperolehnya semakin membaik.(9)

2) Pendidikan Jalur pendidikan formal akan membekali seseorang dengan dasardasar pengetahuan, teori dan logika, pengetahuan umum, kemampuan analisis serta pengembangan kepribadian.(9)

3) Pengalaman Pengalaman adalah suatu sumber pengetahuan atau suatu cara untuk memperoleh kebenaran pengetahuan.(9)

4) Informasi Media komunikasi adalah media yang digunakan pembaca 
untuk mendapatkan informasi sesuatu atau hal tentang pengetahuan.(9)

5) Sosial Budaya Kebudayaan setempat dan kebiasaan dalam keluarga dapat mempengaruhi pengetahuan, persepsi, dan sikap seseorang terhadap sesuatu.

\section{Praktik}

Praktik atau perilaku adalah tindakan atau aktivitas manusia yang memiliki bentangan yang sangat luas. Perilaku merupakan seluruh kegiatan atau aktivitas manusia, baik yang diamati secara langsung, maupun yang tidak diamati dari pihak luar. Setiap individu memiliki perilakunya sendiri yang berbeda dengan individu lain. Namun, secara minimal jika didasari oleh pengetahuan yang cukup, perilaku positif akan terbentuk relatif lama.(10)

Perilaku seseorang atau masyarakat mengenai kesehatan ditentukan oleh pengetahuan, sikap, kepercayaan, tradisi dan sebagainya dari orang atau masyarakat yang bersangkutan. Disamping itu, ketersediaan fasilitas, sikap dan perilaku petugas kesehatan juga mendukung dan memperkuat terbentuknya perilaku.(11)

Instalasi Gawat Darurat (IGD)

Instalasi Gawat Darurat adalah salah satu bagian dari rumah sakit yang menyediakan penanganan awal bagi pasien yang sakit dan cedera, yang dapat mengancam kelangsungan hidup pasien tersebut. Pada Instalasi Gawat Darurat terdapat dokter dari berbagai spesialisasi, sejumlah perawat dan asisten dokter.(12)

\section{Perawat}

Perawat atau Nurse berasal dari bahasa latin yaitu dari kata Nutrix yang berarti merawat atau memelihara. Perawat adalah seseorang yang berperan dalam merawat atau memelihara, membantu dan melindungi seseorang karena sakit. Sebagai tenaga kesehatan, perawat memiliki sejumlah peran di dalam menjalankan tugasnya sesuai dengan hak dan kewenangan yang dimiliki. Peran perawat yang utama adalah sebagai pelaksana, pengelola, pendidik dan peneliti.(7) Perawat IGD merupakan seorang tenaga keperawatan yang bertanggung jawab dan diberi wewenang memberikan pelayanan keperawatan di Instalasi Gawat Darurat.(13)

\section{TUJUAN}

Kajian ini dibuat dengan maksud untuk memberikan pelayanan kesehatan yang baik dan berkualitas dan untuk menganalisis peranan pelaksanaan keselamatan pasien oleh perawat di Ruang IGD

\section{METODE}

Metode penelitian yang digunakan dalam kajian ini adalah kajian yang dibuat dengan menganalisis, mengekplorasi atau menggabungkan kajian kumulatif dan kualitatif dari berbagai sumber ilmiah yang dikembangkan maupun dari berbagai macam buku panduan dan jurnal berdasarkan aturan dan konsep yang sesuai.

\section{HASIL}

Berdasarkan hasil perbandingan dari berbagai sumber ilmiah diperoleh hasil yaitu masih adanya perawat yang belum menerapkan upaya atau pelaksanaan keselamatan pasien di Ruang IGD. Hal ini 
dipengaruhi karena perawat tidak berlandaskan pengetahuan yang penuh atau tingkah pengetahuan yang dimiliki perawat masih rendah.

Meskipun demikian telah di sebutkan dari salah satu jurnal tersebut bahwasanya jika penerapan keselamatan pasien dilakukan dengan baik maka pelayanan yang mengutamakan keselamatan dan kualitas yang optimal akan memberikan dampak yang luas terutama bagi masyarakat yang mendapatkan pelayanan kesehatan dengan aman, berkualitas dan memenuhi harapan klien. Pelayanana yang baik dan berkualitas dapat meningkatkan kepercayaan public terhadap Rumah Sakit tersebut.

\section{PEMBAHASAN}

Budaya keselamatan pasien merupakan persepsi yang dibagikan diantara anggota organisasi ditujukan untuk melindungi pasien dari kesalahan tata laksana maupun cidera akibat intervensi. Persepsi ini meliputi kumpulan norma, standar profesi, kebijakan, komunikasi dan tanggung jawab dalam keselamatan pasien. Budaya keselamatan pasien di dapat diterapkan di berbagai unit yang ada dirumah sakit khususnya budaya keselamatan pasien di ruang instalasi gawat darurat (IGD). Instalasi gawat darurat menyediakan penanganan awal bagi pasien yang menderita sakit dan cidera yang dapat mengancam jiwa dan kelangsungan hidup. Penerapan budaya keselamatan pasien di ruang IGD dapat dilakukan pada setiap pemberian tindakan atau asuhan keperawatan yang di berikan oleh perawat. Budaya keselamatan pasien merupakan bagian penting dalam keseluruhan budaya organisasi yang diperlukan dalam institusi kesehatan. Penerapan budaya keselamatan pasien akan meningkatkan kesadaran untuk mencegah error dan melaporkan jika ada kesalahan. Budaya keselamatan pasien juga dapat mengurangi pengeluaran finansial yang diakibatkan oleh kejadian keselamatan pasien. Membangun budaya keselamatan pasien di rumah sakit menjadi kewajiban dan tanggung jawab seluruh staf yang bekerja di rumah sakit lebih utamanya para tenaga medis yang berhubungan langsung dengan pasien.

\section{PENUTUP}

Budaya keselamatan pasien khususnya diruang instalasi gawat darurat (IGD) sangat penting dilaksanakan dan dilakukan serta ditingkatkan untuk mencapai peningkatan mutu pelayanan kesehatan dan untuk dapat mencegah terjadinya insiden dalam melakukan atau memberikan tindakan ke pada pasien. Hal ini budaya keselamatan pasien dapat di terapkan dengan bantuan para tenaga kesehatan dan staf atau pegawai rumah sakit yang sering berhubungan secara langsung pada pasien.

\section{Daftar Pustaka}

1 .Darliana , D . (2016 ). Hubungan Pengetahuan Perawat dengan Upaya Penerapan Patient Safety di Ruang Rawat Inap Rumah Sakit Umum Daerah Dr..Zainoel Abidin Banda Aceh . Idea Nursing Journal . Vol VII.

2 Gobel, Y. Wahidin \& Muttaqin . (2018) . Kualitas Pelayanan Kesehatan Instalasi Gawat Darurat Rumah Sakit Umum Daerah Kota Makassar Jurnal Administrasi Negara . Vol 4. 
3 Ismainar, H . (2015). Keselamatan Pasien di Rumah Sakit . Penerbit Deepublish .

4 Jaladara, V . Jayanti, S \& Ekawati . (2015) . Hubungan Tingkat Pengetahuan dan Praktik Perawat Mengenai Keselamatan Pasien di Instalasi Gawat Darurat RS X Semarang . Jurnal Kesehatan Masyarakat . Vol 3.

5 Lombogia , A . Rottie , J \& Karundeng , M . (2016) . Hubungan Perilaku dengan Kemampuan Perawat dalam Melaksanakan Keselamatan Pasien (Patient Safety) di Ruang Akut Instalasi Gawat Darurat RSUP Prof. Dr. R . d. Kandou Manado . e-Journal Keperawatan (e-Kp) . Vol 4.

6 Najihah. (2018). Budaya Keselamatan Pasien dan Insiden Keselamatan Pasien di Rumah Sakit. Journal of Nursing, Vol. 3 No. 1: 1-6.

7 Nursalam. (2007). Manajemen Keperawatan Aplikasi Dalam Praktik Keperawatan Profesional. Edisi 2. Jakarta: Salemba Medika.

8 Permenkes RI. (2011). Peraturan Menteri Kesehatan Republik Indonesia Nomor 1691/Menkes/Per/VIII/2011 Tentang Keselamatan Pasien Rumah Sakit. Jakarta: Depkes RI.

9 Permenkes RI. (2017). Peraturan Menteri Kesehatan Republik Indonesia Nomor 11 Tahun 2017 Tentang Keselamatan Pasien. Jakarta: Depkes RI.

10 Rosyada, Sabila D. (2014). Gambaran Budaya Keselamatan Pasien Pada Perawat Unit Rawat Inap Kelas III Rumah sakit Umum Daerah Pasar
Rebo Bulan Juni 2014. Jurnal IImu Kesehatan: 23-28.

11 Simamora, R. H. \& Nurmaini. C. T. S. (2019). Knowledge of Nurses about of Paitent Fail Risk in Inpatient Room of Private Hospital In Medan. Indian Journal Of Public Health Research \& Development, 10(10). 759-763. 